\title{
PENANGANAN RISIKO HUKUM PEMBIAYAAN DI BANK SYARIAH
}

\author{
Trisadini Prasastinah Usanti \\ aditris@ymail.com \\ Fakultas Hukum Universitas Airlangga
}

\begin{abstract}
The most of the assets of syariah banks are financing. On one side it is the largest source of income. however it could be the source of the greatest business risk as well. Therefore, quality of the financing must be protected and kept feasible. The legal issue analyzed in this article is about the efforts being made by Islamic banks to handle legal risks arising from financing. The approach used is the statute approach and conceptual approach. The efforts made by syariah banks in dealing with risk law financing based on two strategies, namely the restructuring of financing or settlement of financing problem.
\end{abstract}

Keywords: legal risk, financing, syariah bank.

\begin{abstract}
Abstrak
Sebagian besar aset dari bank syariah adalah pembiayaan. Di satu sisi pembiayaan merupakan sumber pendapatan yang terbesar namun sekaligus sebagai sumber risiko bisnis yang terbesar pula, sehingga pembiayaan tersebut harus dijaga kualitasnya. Isu hukum yang dikaji adalah apa upaya yang dilakukan oleh bank syariah untuk menangani risiko hukum yang ditimbulkan dari pembiayaan. Pendekatan yang dipergunakan adalah pendekatan peraturan perundang-undangan dan pendekatan konseptual. Upaya yang dilakukan oleh bank syariah dalam menangani risiko hukum pembiayaan didasarkan pada dua strategi, yaitu melakukan restrukturisasi pembiayaan atau menyelesaikan pembiayaan.
\end{abstract}

Kata kunci: risiko hukum, pembiayaan, bank syariah. 


\section{Pendahuluan}

Perbankan Syariah sebagaimana diamanatkan pada Pasal 2 Undang-Undang Nomor 21 Tahun 2008 tentang Perbankan Syariah (UU No. 21/2008) berkewajiban melakukan kegiatan usahanya berasaskan prinsip syariah, demokrasi ekonomi dan prinsip kehati-hatian. Prinsip kehati-hatian adalah pengendalian risiko melalui penerapan peraturan perundangundangan dan ketentuan yang berlaku secara konsisten. Dasar filosofis eksistensi prinsip kehati-hatian pada kegiatan usaha perbankan pada hakikatnya adalah sebagai jaminan kepercayaan masyarakat kepada perbankan.

Pada perbankan syariah, hal ini dimaknai sebagai jaminan atas amanah yang sudah diberikan oleh masyarakat. Oleh karena itu, untuk melindungi kepentingan dana masyarakat maka perbankan syariah wajib memegang teguh prinsip kehati-hatian agar perbankan syariah selaku pemegang amanah dalam keadaan sehat, likuid, solvent dan profitable.

Hubungan hukum bank syariah dengan nasabah didasarkan pada prinsip amanah. Hubungan tersebut idak terbatas pada kepercayaan yang didasarkan pada itikad baik saja tetapi juga kepercayaan yang dilandasi dengan nilai ketauhidan bahwa apa yang dilakukan senantiasa diawasi oleh Allah SWT. Dengan adanya prinsip hubungan ini maka bank dan nasabah meyakini bahwa setiap tindakan yang dilakukan merupakan ibadah, sehingga mencerminkan tujuan dari perbankan syariah yang tidak semata-mata mencari keuntungan (profit oriented) tetapi juga mencari kemakmuran di dunia dan kebahagian di akhirat ( falah oriented $){ }^{1}$

Pembiayaan pada sisi aktiva neraca bank syariah merupakan bagian yang terbesar dari dana operasional. Kenyataan ini menggambarkan bahwa pembiayaan adalah sumber pendapatan bank yang terbesar sekaligus merupakan sumber risiko bisnis yang terbesar. Oleh karena itu, bank syariah wajib menerapkan manajemen risiko sebagaimana diatur dalam Pasal 38 dan Pasal 39 UU No. 21/2008 bahwa Bank Syariah dan Unit Usaha Syariah (UUS) wajib menerapkan manajemen risiko, prinsip mengenal nasabah, dan perlindungan nasabah. Bank Syariah dan UUS wajib menjelaskan kepada Nasabah mengenai kemungkinan timbulnya risiko kerugian sehubungan dengan transaksi Nasabah yang dilakukan melalui Bank Syariah dan/atau UUS.

Pada Peraturan Bank Indonesia Nomor 13/23/PBI/2011 tentang Penerapan Manajemen Risiko Bagi Bank Umum Syariah dan Unit Usaha Syariah, disebutkan ada 10 (sepuluh) macam risiko yang ada pada kegiatan usaha perbankan syariah, yaitu meliputi Risiko Kredit, ${ }^{2}$ Risiko Pasar, Risiko Likuiditas, Risiko Operasional, Risiko Hukum,Risiko Reputasi, Risiko

\footnotetext{
1 Trisadini Prasastinah Usanti, Prinsip Kehati-hatian Pada Transaksi Perbankan Syariah, Airlangga University Press, 201, h. 137.

2 Istilah yang dipergunakan pada Undang-Undang Perbankan Syariah untuk kegiatan usaha penyaluran dana adalah pembiayaan sebagaimana pada Pasal 1 angka 25 Undang-Undang Perbankan Syariah, Namun dalam PBI Nomor 13/23/PBI/2011 tentang Penerapan Manajemen Risiko Bagi Bank Umum Syariah dan Unit Usaha Syariah, menggunakan istilah kredit bukan pembiayaan. hal ini menunjukkan belum adanya konsistensi istilah dalam peraturan perundang-undangan.
} 
Strategik, Risiko Kepatuhan, Risiko Imbal Hasil (Rate of Return Risk) dan Risiko Investasi (Equity Investment Risk).

Risiko hukum ini timbul antara lain karena ketiadaan peraturan perundang-undangan yang mendukung atau kelemahan perikatan, seperti tidak dipenuhinya syarat sahnya kontrak atau pengikatan agunan yang tidak sempurna. Risiko hukum dalam pembiayaan sangat erat dengan risiko kredit (pembiayaan). Dampak yang ditimbulkan dari risiko hukum bagi bank syariah adalah pembiayaan bermasalah. Salah satunya dikarenakan kelemahan perikatan, yaitu pengikatan agunan yang tidak sempurna, akibatnya bank syariah akan kesulitan untuk mengeksekusi agunan tersebut apabila terjadi risiko kredit (pembiayaan). Oleh karena itu, risiko hukum maupun risiko kredit (pembiayaan) harus diidentifikasi, diukur, dipantau, dan dikendalikan.

\section{Pemilihan Strategi Penanganan Pembiayaan Bermasalah}

Bilamana terjadi pembiayaan bermasalah maka bank syariah akan melakukan upaya untuk menangani pembiayaan bermasalah tersebut, agar dana yang telah disalurkan oleh bank syariah dapat diterima kembali. Dikategorikan sebagai pembiayaan bermasalah (non Performing finance/NPF) jika kualitas pembiayaan mulai masuk golongan dalam kurang lancar sampai golongan Macet. ${ }^{3}$

Strategi dalam menangani pembiayaan bermasalah, terdiri dari 2 (dua) pilihan. Pertama, melanjutkan hubungan dengan nasabah. Strategi ini dilakukan apabila nasabah memenuhi beberapa kriteria bahwa nasabah dinilai kooperatif dan masih memiliki prospek usaha, serta melakukan langkah-langkah restruktur (rescheduling, reconditioning atau restructuring). Jika kriteria ini dilakukan maka tahap selanjutnya adalah pihak bank akan menghubungi nasabah dan memberitahukan perihal rencana restrukturisasi atas pembiayaannya. Pihak bank akan melakukan penghimpunan data dan informasi lengkap atas nasabah pembiayaan bermasalah, kemudian pihak bank akan melakukan evaluasi/ analisa restrukturisasi pembiayaan bermasalah dengan menggunakan Analisa Penyelesaian Pembiayaan Bermasalah berdasarkan strategi penyelamatan yang ditetapkan melalui pembahasan bersama.

Strategi kedua dalam menangani pembiayaan bermasalah adalah dengan cara memutuskan hubungan dengan nasabah. Hal ini dilakukan apabila nasabah dinilai tidak kooperatif dan/atau sudah tidak memiliki prospek usaha. Maka penyelesaian pembiayaan dilakukan melalui: Penyerahanan Agunan/Aset (Offset) atau Litigasi yang berupa eksekusi objek jaminan dan gugatan Perdata.

Terdapat faktor-faktor lain yang juga mempengaruhi pemilihan sasaran strategi yaitu: 1) Tingkat kerjasama dengan nasabah; 2) Penetapan lamanya waktu proses yang jelas

3 Berdasarkan Pasal 8 Peraturan Bank Indonesia Nomor:13/13 /PBI/2011 tentang Penilaian Kualitas Aktiva Bagi Bank Umum Syariah dan Unit Usaha Syariah bahwa Kualitas Pembiayaan ditetapkan menjadi 5 (lima) golongan, yaitu Lancar, Dalam Perhatian Khusus, Kurang Lancar, Diragukan dan Macet. 
dan rasional; 3) Biaya dan manfaat dalam pelaksanaan strategi; 4) Pengawasan Bank misal; letak geografik, media komunikasi dan sebagainya.

\section{Penyelamatan Pembiayaan Bermasalah}

Berdasarkan Peraturan Bank Indonesia Nomor 13/9/PBI/2011 tentang Perubahan atas Peraturan Bank Indonesia Nomor 10/PBI/2008 tentang Restrukturisasi Pembiayaan Bagi Bank Syariah dan Unit Usaha Syariah, restrukturisasi pembiayaan adalah upaya yang dilakukan bank dalam rangka membantu nasabah agar dapat menyelesaikan kewajibannya antara lain melalui penjadwalan kembali, persyaratan kembali dan penataan kembali.

Bank syariah hanya dapat melakukan restrukturisasi pembiayaan terhadap nasabah yang memenuhi kriteria sebagai berikut; 1) nasabah mengalami penurunan kemampuan pembayaran; dan 2) nasabah memiliki prospek usaha yang baik dan mampu memenuhi kewajiban setelah restrukturisasi. Restrukturisasi untuk pembiayaan konsumtif hanya dapat dilakukan untuk nasabah dengan kriteria bahwa nasabah mengalami penurunan kemampuan pembayaran dan terdapat sumber pembayaran angsuran yang jelas dari nasabah dan mampu memenuhi kewajiban setelah restrukturisasi.

Restrukturisasi pembiayaan wajib didukung dengan analisis dan bukti-bukti yang memadai serta didokumentasikan dengan baik. Di samping 2 (dua) kriteria di atas bank syariah akan melakukan penyelamatan pembiayaan bermasalah dengan upaya restrukturisasi apabila nasabah masih mempunyai itikad baik dalam arti masih mau diajak kerjasama dalam upaya penyelamatan pembiayaan bermasalah, akan tetapi jika nasabah sudah tidak beritikad baik dalam arti tidak dapat diajak kerjasama dalam upaya penyelamatan pembiayaan bermasalah maka bank syariah akan melakukan upaya penyelesaian pembiayaan bermasalah. Secara ringkas restrukturisasi pembiayaan nampak pada tabel 1 mengenai upaya restrukturisasi pembiayaan di bank syariah.

Adapun landasan syariah yang mendukung upaya restrukturisasi pembiayaan, yaitu: dinyatakan dalam surat Al Baqarah (2): 276: "Allah memusnahkan riba dan menyuburkan sedekah dan Allah tidak menyukai setiap orang yang tetap dalam kekafiran dan selalu berbuat dosa". Kemudian dalam surat Al Baqarah (2): 280: "dan jika (orang berhutang itu) dalam kesukaran, maka berilah tangguh sampai dia berkelapangan dan menyedekahkan (sebagian atau semua hutang) itu lebih baik bagimu, jika kamu mengetahui". Dalam surat urat Al Baqarah (2): 286 Allah berfirman "Allah tidak membebani seseorang melainkan sesuai dengan kesanggupannya. Ia mendapat pahala (atas kebajikan) yang diusahakannya dan ia mendapat siksa (dari kejahatan) yang dikerjakannya". Dari kutipan ayat Al Quran diatas selalu digaris bawahi pentingnya sedekah dan tuntunan akan perlunya toleransi terhadap nasabah bila menghadapi nasabah sedang mengalami kesulitan (dalam arti sebenarbenarnya) membayar kembali kewajibannya. Dalam hadits Nabi riwayat Muslim, "Orang yang melepaskan seorang muslim dari kesulitannya di dunia, Allah akan melepaskan 
kesulitannya di hari kiamat; dan Allah senantiasa menolong hamba-Nya selama ia (suka) menolong saudaranya”.

\section{Tabel 1. Upaya Restrukturisasi Pembiayaan di Bank Syariah}

\begin{tabular}{|c|c|c|}
\hline $\begin{array}{c}\text { Penjadwalan kembali } \\
\text { (rescheduling) }\end{array}$ & $\begin{array}{c}\text { Persyaratan kembali } \\
\text { (reconditioning) }\end{array}$ & \\
\hline $\begin{array}{l}\text { Perubahan jadwal pembayaran } \\
\text { kewajiban nasabah atau jangka } \\
\text { waktunya. } \\
\text { Berdasarkan SEBI No.13/18/ } \\
\text { DPbS tanggal } 30 \text { Mei } 2011 \text { yang } \\
\text { dimaksud dengan Penjadwalan } \\
\text { kembali (rescheduling), yaitu } \\
\text { perubahan jadwal pembayaran } \\
\text { kewajiban nasabah atau jangka } \\
\text { waktu pembayaran kewajiban } \\
\text { tersebut. Akan tetapi, tidak } \\
\text { termasuk perpanjangan atas } \\
\text { pembiayaan mudharabah atau } \\
\text { musyarakah yang memenuhi } \\
\text { kualitas lancar dan telah jatuh } \\
\text { tempo serta bukan disebabkan } \\
\text { nasabah mengalami penurunan } \\
\text { kemampuan membayar. }\end{array}$ & $\begin{array}{l}\text { Perubahan atas sebagian } \\
\text { atau seluruh persyaratan } \\
\text { pembiayaan tanpa menambah } \\
\text { sisa pokok kewajiban nasabah } \\
\text { yang harus dibayarkan kepada } \\
\text { bank, antara lain meliputi: } \\
\text { a. perubahan } \\
\text { pembayaran; } \\
\text { b. perubahan } \\
\text { angsuran; jumlah } \\
\text { c. perubahan jangka waktu; } \\
\text { d. perubahan nisbah dalam } \\
\text { pembiayaan mudharabah } \\
\text { atau musyarakah; } \\
\text { e. perubahan proyeksi bagi } \\
\text { hasil dalam pembiayaan } \\
\text { mudharabah } \\
\text { musyarakah; dan/atau: } \\
\text { f. pemberian potongan. }\end{array}$ & $\begin{array}{l}\text { Perubahan atas persyaratan } \\
\text { pembiayaan yang antara lain } \\
\text { meliputi: } \\
\text { 1) penambahan dana fasilitas } \\
\text { Pembiayaan Bank; } \\
\text { 2) konversi akad Pembiayaan; } \\
\text { 3) konversi Pembiayaan } \\
\text { menjadi surat berharga } \\
\text { syariah berjangka waktu } \\
\text { menengah; dan/atau; } \\
\text { 4) konversi Pembiayaan } \\
\text { menjadi penyertaan wmodal } \\
\text { sementara pada perusahaan } \\
\text { nasabah, yang dapat disertai } \\
\text { dengan rescheduling atau } \\
\text { reconditioning. }\end{array}$ \\
\hline
\end{tabular}

\section{Restrukturisasi Per Jenis Akad}

Pembiayaan dalam bentuk piutang, yaitu murabaha dan istishna dapat dilakukan restrukturisasi juga dengan 3 (tiga) cara penjadwalan kembali (reschedulling), persyaratan kembali (reconditioning), dan penataan kembali (restructuring). Penjadwalan kembali (reschedulling) dilakukan dengan memperpanjang jangka waktu jatuh tempo pembiayaan tanpa mengubah sisa kewajiban nasabah yang harus dibayarkan kepada bank. Persyaratan kembali (reconditioning) dilakukan dengan menetapkan kembali syarat-syarat pembiayaan antara lain perubahan jadwal pembayaran, jumlah angsuran, jangka waktu dan/atau pemberian potongan sepanjang tidak menambah sisa kewajiban nasabah yang harus dibayarkan kepada bank. ${ }^{4}$ Penataan kembali (restructuring) dengan melakukan konversi piutang murabahah atau piutang istishna sebesar sisa kewajiban nasabah menjadi ijarah muntahiyah bittamlik atau mudharabah atau musyarakah.

Berdasarkan fatwa Dewan Syariah Nasional konversi piutang dilakukan dengan cara sebagai berikut: ${ }^{5}$ Jika akadnya murabahah maka dihentikan dengan cara; 1) Objek murabahah dijual oleh nasabah kepada LKS dengan harga pasar; 2) Nasabah melunasi sisa hutangnya kepada LKS dari hasil penjualan; 3) Apabila hasil penjualan melebihi sisa hutang

4 Lihat Fatwa Dewan Syariah Nasional Nomor 46/DSN-MUI/II/2005 tentang Potongan Tagihan Murabahah (Khashm Fi Al-Murabahah).

5 Lihat Fatwa Dewan Syariah Nasional Nomor 49/DSN-MUI/II/2005 tentang Konversi Akad Murabahah. 
maka kelebihan itu dapat dijadikan uang muka untuk akad ijarah atau bagian modal dari mudharabah dan musyarakah; 4) Apabila hasil penjualan lebih kecil dari sisa hutang maka sisa hutang tetap menjadi hutang nasabah yang cara pelunasannya disepakati antara LKS dan nasabah.

LKS dan nasabah eks-murabaha tersebut dapat membuat akad baru dengan akad: 1) Ijarah muntahiyah Bit Tamlik atas barang tersebut di atas dengan merujuk kepada Fatwa DSN No.27/DSN-MUI/III/2002 tentang Al Ijarah Muntahiyah Bit Tamlik; 2) Mudharabah dengan merujuk kepada Fatwa DSN No.7/DSN-MUI/IV/2000 tentang pembiayaan mudharabah; 3) Musyarakah dengan merujuk kepada Fatwa DSN-MUI No.8/DSN-Mui/IV/2000 tentang pembiayaan musyarakah.

Pembiayaan mudharabah dan musyarakah dapat dilakukan proses restrukturisasi dengan penjadwalan kembali (reschedulling), persyaratan kembali (reconditioning), penataan kembali (restructuring), dan penataan kembali (restructuring). Penjadwalan kembali (reschedulling) dilakukan dengan memperpanjang jangka waktu jatuh tempo tanpa mengubah sisa kewajiban nasabah yang harus dibayarkan kepada bank. Persyaratan kembali (reconditioning), yang dilakukan dengan menetapkan kembali syarat-syarat pembiayaan antara lain perubahan jadwal pembayaran, jumlah angsuran, jangka waktu dan/atau pemberian potongan. Penataan kembali (restructuring) dengan penambahan dana oleh bank kepada nasabah agar kegiatan usaha nasabah dapat kembali berjalan.

Penataan kembali (restructuring) dengan melakukan konversi menjadi penyertaan modal sementara, dilakukan sebagai berikut: ${ }^{6}$ 1) Penyertaan modal sementara hanya dapat dilakukan pada nasabah yang merupakan badan usaha berbentuk badan hukum perseroan terbatas; 2) Bank menghentikan akad pembiayaan dalam bentuk mudharabah atau musyarakah; 3) Bank membuat akad musyarakah dengan nasabah untuk penyertaan modal sementara sesuai kesepakatan dengan nasabah atas usaha yang dilakukan; 4) Bank melakukan penyertaan modal sementara sebesar sisa kewajiban nasabah.

Sisa kewajiban nasabah dalam restrukturisasi akad pembiayaan mudharabah dan musyarakah merupakan jumlah pokok yang belum dibayar oleh nasabah pada saat dilakukan restrukturisasi.Pembiayaan qardh dapat dilakukan proses restrukturisasi dengan penjadwalan kembali ((reschedulling) yang dilakukan dengan memperpanjang jangka waktu jatuh tempo tanpa mengubah sisa kewajiban nasabah yang harus dibayarkan kepada bank dan persyaratan kembali (reconditioning) yang dilakukan dengan menetapkan kembali syarat-syarat pembiayaan antara lain perubahan jadwal pembayaran, jumlah angsuran, jangka waktu dan/ atau pemberian potongan sepanjang tidak menambah sisa kewajiban nasabah yang harus dibayarkan kepada bank.

Dalam Fatwa Dewan Syariah Nasional No: 19/DSN-MUI/IV/2001 tentang AlQardh. Jika nasabah tidak dapat mengembalikan sebagian atau seluruh kewajibannya pada 
saat yang telah disepakati dan LKS telah memastikan ketidakmampuannya, LKS dapat memperpanjang jangka waktu pengembalian atau menghapus (write off) sebagian atau seluruh kewajibannya. ${ }^{7}$ LKS dapat memberikan sanksi kepada nasabah dalam hal nasabah tidak menunjukkan keinginan mengembalikan sebagian atau seluruh kewajibannya dan bukan karena ketidakmampuannya. Sanksi yang dijatuhkan kepada nasabah sebagaimana dimaksud butir 1 dapat berupa dan tidak terbatas pada penjualan barang jaminan. Jika barang jaminan tidak mencukupi, nasabah tetap harus memenuhi kewajibannya secara penuh. ${ }^{8}$

Pembiayaan ijarah dan ijarah muntahitah bittamlik dapat dilakukan restrukturisasi dengan penjadwalan kembali (reschedulling) yang dilakukan dengan memperpanjang jangka waktu jatuh tempo dan bank dapat menetapkan kembali ujrah yang harus dibayar nasabah dengan jangka waktu perpanjangan paling lama sampai dengan umur ekonomis aktiva ijarah. Lalu dilakukan persyaratan kembali (reconditioning) dilakukan dengan menetapkan kembali syarat-syarat pembiayaan antara lain jumlah angsuran, jangka waktu, jadwal pembayaran, pemberian potongan ujrah dan/atau lainnya. setelah dilakukan persyaratan kembali maka dapat dilakukan penataan kembali (restructuring) dengan melakukan konversi akad ijarah atau ijarah muntahiyah bittamlik menjadi mudharabah atau musyarakah.

Bank syariah melakukan restrukturisasi menjadi akad pembiayaan baru dengan mempertimbangkan kondisi nasabah yang meliputi: 1) Kolektibilitas nasabah; 2) Jenis usaha; 3) Kemampuan membayar (cash flow) nasabah. Penataan kembali (restructuring) dengan melakukan konversi menjadi penyertaan modal sementara hanya dapat dilakukan pada nasabah yang merupakan badan usaha berbentuk badan hukum perseroan terbatas. Bank menghentikan akad pembiayaan dalam bentuk ijarah atau ijarah muntahiyah bittamlik dengan memperhitungkan nilai wajar aktiva ijarah. Bank membuat akad musyarakah dengan nasabah untuk penyertaan modal sementara sesuai kesepakatan dengan nasabah atas usaha yang dilakukan. Bank melakukan penyertaan modal sementara nilai wajar aktiva ijarah.

Pembiayaan yang telah direstrukturisasi wajib dilakukan monitoring secara berkesinambungan dan tepat waktu dengan dianalisa perkembangan penyelesaian dan mengambil langkah-langkah preventif yang diperlukan apabila ditemukan potensi masalah baru, dengan memberi petunjuk dan arahan pada nasabah untuk segera memperbaiki keadaan keuangannya.

\section{Penyelesaian Pembiayaan Bermasalah Melalui Penyerahan Agunan (AYDA)}

Upaya penyelesaian pembiayaan bermasalah dilakukan bilamana upaya penyelamatan pembiayaan bermasalah yang telah dilakukan oleh bank syariah tidak membawa hasil atau sejak awal nasabah penerima fasilitas tidak beritikad baik untuk menyelesaikan pembiayaan

7 Dalam surat Al-Baqarah (2) ayat 280: “.. Dan jika orang yang berhutang di dalam kesempitan, tunggulah sehingga waktu lapang dan jika kamu sedekahkan, lebih baik bagimu jika kamu mengetahui”.

8 Ketentuan umum dalam fatwa tentang al qardh juga diatur sama dalam Pasal 612 sampai Pasal 617 Kompilasi Hukum Ekonomi Syariah, Peraturan Mahkamah Agung Nomor 2 Tahun 2008. 
bermasalah, maka upaya yang dilakukan oleh bank syariah adalah upaya penyelesaian pembiayaan bermasalah, ada beberapa upaya yang dapat dilakukan oleh bank syariah bergantung pada kondisi yang dihadapi oleh nasabah.

Istilah dalam Peraturan Bank Indonesia Nomor 10/PBI/2008 Tentang Restrukturisasi Pembiayaan Bagi Bank Syariah dan Unit Usaha Syariah adalah Agunan yang Diambil Alih yang untuk selanjutnya disebut AYDA adalah aktiva yang diperoleh Bank, baik melalui pelelangan maupun diluar pelelangan berdasarkan penyerahan secara sukarela oleh pemilik agunan atau berdasarkan kuasa untuk menjual diluar lelang dari pemilik agunan dalam hal nasabah tidak memenuhi kewajibannya kepada Bank.

Penyelesaian pembiayaan bermasalah melalui mekanisme penyerahan agunan secara sukarela (Offset) dengan kriteria nasabah mempunyai prospek usaha tidak baik / kemampuan membayar sudah tidak ada lagi, karakter nasabah tidak baik (tidak mau membayar angsuran) dan kualitas pembiayaan kolektibilitas kurang lancar, diragukan dan macet.

Tujuan penyelesaian melalui penyerahan agunan dan langkah penanganan pembiayaan melalui upaya penyelesaian ini dilaksanakan apabila upaya restrukturisasi atau penagihan tidak berhasil atau sulit dilakukan. Pelaksanaannya dengan melakukan pendekatan kepada nasabah tersebut ataupun kepada pemilik agunan agar bersedia membayar atau melunasi kewajibannya pada bank syariah serta melakukan upaya penyelesaian yang lebih intensif kepada nasabah atau pemilik agunan baik melalui pemberian surat pemberitahuan atau surat peringatan dan sebagainya yang bertujuan agar nasabah tersebut bersedia membayar atau melunasi kewajibannya pada bank syariah.

Dilakukannya proses penyelesaian pembiayaan melalui penjualan barang yang menjadi agunan pembiayaan/aset nasabah yang lain adalah agar hasil penjualannya dapat dipergunakan sebagai pelunasan atau pembayaran kewajibannya pada bank syariah.

Penjualan agunan dapat dilakukan kepada pihak lain (yang tidak terkait hubungan hukum dengan bank syariah), baik dilakukan sendiri oleh nasabah atau pemilik agunan, ataupun dengan bantuan bank syariah dalam kapasitasnya sebagai perantara transaksi penjualan barang. Penjualan agunan juga dapat dilakukan kepada Bank Syariah atau dengan kata lain dibeli sendiri oleh bank Syariah melalui pejabat/karyawan yang ditunjuk untuk itu ataupun langsung oleh bank syariah, umumnya dikenal dengan istilah Offset Agunan sebagaimana diatur pada Pasal 40 UU No. 21/2008 dengan catatan, agunan yang dibeli wajib dicairkan selambat-lambatnya dalam jangka waktu 1 (satu) tahun. Dalam hal harga pembelian agunan melebihi jumlah kewajiban nasabah kepada bank syariah dan UUS, selisih kelebihan jumlah tersebut harus dikembalikan kepada nasabah setelah dikurangi dengan biaya lelang dan biaya lain yang terkait langsung dengan proses pembelian agunan.

Penjualan agunan kepada pihak ketiga atau pihak lain dilaksanakan dengan memperhatikan hal-hal sebagai berikut: 1) Kedudukan bank hanya sebagai pihak yang membantu mencarikan calon pembeli dan membantu kelancaran transaksi jual belinya 
serta tidak terlibat langsung atas pelaksanaan jual beli antara pemilik dan calon pembeli; 2) Kedudukan bank memberikan persetujuan dalam arti bank selaku kreditor pemegang jaminan;9 3) Kedudukan bank hanya mengatur uang hasil penjualan objek agar tidak jatuh ke tangan pemiliknya akan tetapi langsung disetor pada bank sebagai pelunasan hutannya.

Penjualan agunan kepada pihak bank atau aparat yang ditunjuk (dalam perbankan dikenal dengan istilah offsetting dilaksanakan dengan memperhatikan hal-hal sebagai berikut: ${ }^{10}$ 1) Bahwa offset hanya merupakan salah satu bentuk penyelesaian pembiayaan bermasalah yang dilakukan penjualan agunan dengan pihak bank atau pejabat yang ditunjuk untuk sebagai pembeli. 2) Bahwa offset dilakukakan bermaksud untuk menyelesaikan kewajiban nasabah pada bank; 3) Bahwa pelaksanaan jual beli wajib memperhatikan peraturan perundang-undangan. Pembelian agunan dapat dilaksanakan setelah dilakukan retaksasi agunan dan nilai pembelian agunan maksimal sebesar nilai pasar setelah diretaksasi bank.

\section{Penyelesaian Pembiayaan Bermasalah Melalui Jaminan}

Penyelesaian melalui jaminan dilakukan oleh bank syariah bilamana berdasarkan evaluasi ulang pembiayaan, prospek usaha nasabah tidak ada, dan atau nasabah tidak kooperatif untuk menyelesaikan pembiayaan atau upaya penyelamatan dengan upaya restrukturisasi tidak membawa hasil melancarkan kembali pembiayaan tersebut. Maka upaya penyelesaian pembiayaan bermasalah dengan cara eksekusi objek jaminan akan dilakukan oleh bank syariah dengan catatan bahwa objek jaminan tersebut dibebani lembaga jaminan sesuai dengan prosedur yang ditentukan oleh undang-undang.

Landasan syariah yang berkaitan dengan jaminan dalam surat Al Baqarah (2): 283 "Jika kamu dalam perjalanan (dan kamu bermuamalah/jual beli tidak secara tunai), sedang kamu tidak memperoleh seorang penulis, maka hendaklah ada barang tanggungan yang dipegang oleh si berpiutang...".

Diriwayatkan oleh Aisyah r.a. bahwasanya Nabi Muhammad saw pernah membeli bahan makanan dari seorang Yahudi dengan hutang dan beliau memberikan baju besinya sebagai jaminan (HR.Bukhari, Muslim dan Nasa'i). Dari Abu Hurairah r.a. bahwa Rasulullah bersabda "Siapapun yang bangkrut (muflis), lalu kreditornya mendapatkan barangnya sendiri pada si muflis, maka kreditor itu lebih berhak untuk menarik kembali barangnya daripada orang lain (HR.Bukhari, Muslim, Tirmidzi, Nasa'i dan Ibnu Majah

\section{Penyelesaian Melalui Badan Arbitrase Syariah Nasional}

Pada Pasal 20 ayat (2) Peraturan Bank Indonesia Nomor 7/46/PBI/ 2005 tentang Akad Penghimpunan dan Penyaluran Dana bagi Bank yang Melaksanakan Kegiatan Usaha

\footnotetext{
9 Lihat pasal 11 ayat (2) g Undang-Undang Nomor 4 Tahun 1996 tentang Hak Tanggungan

10 Lihat pasal 40 UU No. 21/2008
} 
Berdasarkan Prinsip Syariah menyatakan bahwa : "Dalam hal musyawarah tidak mencapai kesepakatan maka penyelesaian lebih lanjut dapat dilakukan melalui alternatif penyelesaian sengketa atau Badan Arbitrase Syariah.” Demikian juga dalam Pasal 4 ayat (3) Peraturan Bank Indonesia Nomor 9/19/PBI/2007 tentang Pelakssanaan Prinsip Syariah dalam Kegiatan Penghimpunan Dana dan Penyaluran Dana serta Pelayanan Jasa Bank Syariah, penyelesaian sengketa perbankan syariah melalui mekanisme arbitrase syariah baru dapat dilakukan jika penyelesaian sengketa melalui mediasi, termasuk mediasi perbankan tidak mencapai kesepakatan. Jadi, mekanisme arbitrase syariah baru dapat dilakukan jika penyelesaian sengketa perbankan syariah melalui musyawarah dan mediasi tidak mencapai kata sepakat.

Pada Peraturan Bank Indonesia tersebut dinyatakan bahwa forum penyelesaian sengketa perbankan syariah diatur secara berjenjang, yaitu diawali dengan penyelesaian melalui musyawarah, kemudian melalui mediasi termasuk mediasi perbankan. Jika musyawarah tidak mencapai kesepakatan. Maka dapat dilanjutkan melalui melalui arbitrase syariah atau lembaga peradilan bilamana penyelesaian sengketa melalui mediasi perbankan juga tidak mencapai kesepakatan.

Seperti dikemukakan di atas berdasarkan fatwa-fatwa Dewan Syariah Nasional, bahwa bilamana terjadi perselisihan antara lembaga keuangan syariah dengan nasabahnya, maka penyelesaian dilakukan melalui musyawarah, terkecuali tidak mencapai kesepakatan, dilakukan penyelesaiannya melalui Basyarnas. Keputusan yang dibuat oleh Basyarnas mempunyai kekuatan mengikat. Pengadilan tidak berwenang untuk mengadili sengketa para pihak yang telah terikat dalam perjanjian arbitrase. Putusan arbitrase bersifat final and binding, ${ }^{11}$ yang berarti mempunyai kekuatan hukum tetap dan mengikat, tidak ada banding, kasasi maupun peninjauan kembali. Oleh karena itu, para pihak harus melaksanakan putusan Basyarnas tersebut secara sukarela.

\section{Penyelesaian Melalui Litigasi}

Bank akan menempuh penyelesaian lewat litigasi apabila nasabah tidak beritkad baik, yaitu tidak menunjukkan kemauan untuk memenuhi kewajibannya sedangkan nasabah sebenarnya masih mempunyai harta kekayaan yang tidak dikuasai oleh bank atau sengaja menyembunyikan atau mempunyai sumber-sumber lain untuk menyelesaikan kredit macetnya. Berdasarkan ketentuan dalam Pasal 49 Undang-Undang Nomor 3 Tahun 2006 tentang Peradilan Agama (UU No. 3/2006), maka kewenangan penyelesaian sengketa perbankan syariah juga menjadi kompetensi absolut dari Pengadilan Agama dalam lingkungan peradilan agama, bahkan meliputi pula bidang ekonomi syariah lainnya di luar bidang perbankan syariah. Berdasarkan penjelasan Pasal 49 UU No. 3/2006 tersebut, maka seluruh nasabah lembaga keuangan dan lembaga pembiayaan syariah, atau bank konvensional yang

11 Berdasarkan Pasal 60 Undang-Undang Nomor 30 tahun 1999 tentang Arbitrase dan Alternatif Penyelesaian Sengketa, yang mengatur bahwa "putusan arbitrase bersifat final dan mempunyai kekuatan hukum tetap dan mengikat para pihak." 
membuka unit usaha syariah dengan sendirinya terikat dengan ketentuan ekonomi syariah, baik dalam pelaksanaan akad maupun dalam penyelesaian perselisihan.

Pada UU No. 21/2008 kembali dipertegas bahwa sengketa perbankan syariah merupakan salah satu kewenangan pengadilan dalam lingkungan peradilan agama sebagaimana ditentukan dalam Pasal 55 ayat (1) UU No. 21/2008, yaitu: "Penyelesaian sengketa perbankan syariah dilakukan oleh pengadilan dalam lingkungan peradilan agama". Pasal 55 ayat (2) UU No. 21/2008 menyebutkan "Dalam hal para pihak telah memperjanjikan penyelesaian sengketa selain sebagaimana dimaksud pada Pasal 55 ayat (1) UU No. 21/2008, penyelesaian sengketa dilakukan sesuai dengan isi Akad". Penjelasan dari Pasal 55 ayat (2) UU No. 21/2008 menyebutkan bahwa yang dimaksud dengan penyelesaian sengketa sesuai dengan isi akad adalah upaya dengan musyawarah, mediasi perbankan, badan arbitrase syariah nasional atau lembaga arbitrase lain serta melalui pengadilan dalam lingkungan peradilan umum.

Berdasarkan hukum perjanjian, maka ketentuan Pasal 55 ayat (2) UU No. 21/2008 lahir karena adanya asas kebebasan berkontrak. Islam memberikan kebebasan kepada para pihak untuk melakukan suatu perikatan. Bentuk dan isi perikatan tersebut ditentukan oleh para pihak. Apabila telah disepakati bentuk dan isinya maka perikatan tersebut mengikat para pihak yang telah menyepakatinya dan harus dilaksanakan segala hak dan kewajibannya. Namun kebebasan ini tidak absolut, sepanjang tidak bertentangan dengan syariah Islam, maka perikatan tersebut boleh dilaksanakan. ${ }^{12}$

Adanya pemilihan forum dalam penyelesaian sengketa perbankan syariah berdasarkan Pasal 55 ayat (2) UU No. 21/2008 menunjukkan inkonsistensi pembentuk undang-undang dalam merumuskan aturan hukum. Pasal 49 UU No. 3/2006 secara jelas memberikan kompetensi kepada Pengadilan Agama untuk mengadili sengketa ekonomi syariah, termasuk perbankan syariah sebagai suatu kompetensi absolut.

Ketentuan Pasal 55 ayat (2) UU No. 21/2008 beserta penjelasannya telah diuji materiil oleh Mahkamah Konstitusi dalam Putusannya Nomor 93/PUU-X/2012 pada tanggal 29 Agustus 2013 bahwa: 1) Penjelasan Pasal 55 ayat (2) UU No. 21/2008 tentang Perbankan Syariah (Lembaran Negara Republik Indonesia Tahun 2008 Nomor 94, Tambahan Lembaran Negara Republik Indonesia Nomor 4867) bertentangan dengan Undang-Undang Dasar Negara Republik Indonesia Tahun 1945; 2) Penjelasan Pasal 55 ayat (2) UU No. 21/2008 tentang Perbankan Syariah (Lembaran Negara Republik Indonesia Tahun 2008 Nomor 94, Tambahan Lembaran Negara Republik Indonesia Nomor 4867) tidak mempunyai kekuatan hukum mengikat.

Mahkamah Konstitusi berpendapat bahwa adanya pilihan penyelesaian sengketa (choice of forum) untuk menyelesaikan sengketa dalam perbankan syariah sebagaimana tersebut dalam Penjelasan Pasal 55 ayat (2) UU No. 21/2008 a quo pada akhirnya akan

12 Gemala Dewi, dkk., Hukum Perikatan Islam di Indonesia, Kencana, 2005, h. 31. 
menyebabkan adanya tumpang tindih kewenangan untuk mengadili oleh karena ada dua peradilan yang diberikan kewenangan untuk menyelesaikan sengketa perbankan syariah sedangkan dalam undang-undang yang lain (UU Peradilan Agama) secara tegas dinyatakan bahwa peradilan agama diberikan kewenangan untuk menyelesaikan sengketa perbankan syariah termasuk juga sengketa ekonomi syariah.

Menurut Mahkamah, adalah hak nasabah dan juga unit usaha syariah untuk mendapatkan kepastian hukum sebagaimana ditentukan dalam Pasal 28 D ayat (1) UUD 1945. Mahkamah menilai ketentuan Penjelasan Pasal 55 ayat (2) UU No. 21/2008 a quo tidak memberi kepastian hukum. Berdasarkan kenyataan yang demikian, walaupun Mahkamah tidak mengadili perkara konkrit, telah cukup bukti bahwa ketentuan Penjelasan pasal $a$ quo telah menimbulkan ketidakpastian hukum yang adil dan hilangnya hak konstitusional nasabah untuk mendapatkan kepastian hukum yang adil dalam penyelesaian sengketa perbankan syariah menyebabkannya bertentangan dengan prinsip-prinsip konstitusi.

\section{Hapus Buku dan Hapus Tagih}

Hapus Buku (write off) adalah merupakan tindakan intern bank syariah yang bersifat administratif dengan cara, kriteria dan prosedur tertentu, yaitu menghapus-bukukan tagihan kewajiban nasabah dari pembukuan neraca bank syariah (on balance sheet) dengan memindahkan pencatatannya menjadi di luar pembukuan neraca bank syariah tanpa menghapus hak tagih bank kepada nasabah. Tagihan kewajiban adalah tagihan bank yang timbul karena adanya kewajiban-kewajiban nasabah yang seharusnya dibayarkan kepada bank sebagai akibat adanya pemberian fasilitas pembiayaan dari bank syariah atau transaksi lainnya sesuai dengan ditetapkan dalam perjanjian dan disepakati bersama. Termasuk di dalam pengertian tagihan meliputi pokok pembiayaan ataupun kewajiban-kewajiban lainnya tetapi tidak terbatas marjin keuntungan yang akan diterima bank syariah. Marjin keuntungan yang dimaksud di atas meliputi marjin yang sudah menjadi kewajiban yang seharusnya sudah dibayar nasabah (telah menjadi tunggakan nasabah) ataupun belum menjadi kewajiban nasabah (belum termasuk dalam tunggakan nasabah namun termasuk dalam perhitungan harga jual).

Hapus buku tidak berarti kewajiban tunggakan nasabah kepada bank syariah telah dinyatakan lunas atau tidak ada lagi hak tagih bank syariah kepada nasabah ataupun hubungan hukum. Selain hapus buku terdapat juga hapus tagih yang bersifat mutlak, yaitu dengan sendirinya kewajiban tunggakan nasabah kepada bank syariah dinyatakan lunas atau bank syariah tidak memiliki hak tagih ( hair cut) kepada nasabah, atau lazim dikenal sebagai Pembebasan tagihan. Hapus tagih adalah pembebasan yang diberikan bank syariah kepada nasabah untuk membayar kewajibannya kepada bank, berupa pembebasan seluruh ataupun sebagian tagihan yang berasal dari kewajiban-kewajiban nasabah yang telah disepakati.

Hapus buku tagihan merupakan kebijakan bank karenanya baik hapus buku tagihan 
bersifat mutlak (hapus tagih/hair cut) atau hapus buku tagihan secara administratif bersifat sangat rahasia karenanya bank syariah tidak diijinkan atau dibolehkan memberitahukan kepada nasabah atau pihak-pihak lain yang tidak mempunyai wewenang untuk itu. Dalam melaksanakan hapus buku wajib dilakukan dengan menghindari dampak negatif atau yang merugikan bagi pihak bank baik secara langsung atau tidak langsung.

Kriteria pembiayaan yang dapat diusulkan untuk dihapus buku adalah sebagai berikut: 1) Pembiayaan yang sudah berkolektibilitas macet; 2) PPAP telah dibentuk $100 \%$ tanpa memperhitungkan nilai agunan, dilampiri proofsheet PPAP posisi terakhir; 3) Terpenuhinya kelengkapan administrasi, seperti surat peringatan I,II dan III yang diterima oleh nasabah secara patut, baik dikirim langsung maupun melalui jasa pengiriman, bukti pengiriman dan tanda terima surat yang ditandatangani oleh nasabah atau yang menerimanya agar disimpan dengan baik, mengingat dokumen terdapat dapat menjadi bukti saat litigasi, adanya surat pernyataan/kesepakatan dari nasabah mengenai pembayaran yang tidak ditepati, serta adanya bukti tidak terbayarnya cessie yang merupakan agunan dari pembiayaan tersebut minimal berupa surat penagihan dari bank; 4) Bila nasabah memiliki lebih dari 1 (satu) pembiayaan, maka hapus buku tidak dapat dilakukan terhadap salah satu atau sebagian pembiayaan (write off partial).

Sebelum bank akan melakukan hapus buku (write off) atas pembiayaan nasabah maka harus dipersiapkan data yang dibutuhkan, yaitu meliputi: 1) Data Nasabah; 2) Data Fasilitas Pembiayaan; 3) Data Agunan; 4) Data yang berisi fakta/informasi latar belakang penyebab pembiayaan menjadi bermasalah dan upaya-upaya yang telah dilakukan oleh bank dan hasil dari upaya tersebut; 5) Data yang berisi rencana penyelesaian dengan pertimbanganpertimbangan yang akan mempercepat dan memperkuat rencana tersebut. Berdasarkan data-data tersebut maka dibuatkan kesimpulan dan rekomendasi, antara lain: 1) Nominal pembiayaan yang dihapus buku; 2) Usulan potongan (muqasah) atas margin/proyeksi bagi hasil yang telah jatuh tempo; 3) Pihak bank akan tetap menagih/menyelesaikan pembiayaan.

Hapus tagih (hair cut) merupakan salah satu cara hapusnya perikatan sebagaimana diatur dalam Pasal 1318 Burgerlijk Wetboek (BW). Dalam BW tidak ada rumusan yang menjelaskan tentang pembebasan utang. Namun demikian rumusan pembebasan utang dapat diartikan sebagai suatu perbuatan yang dilakukan oleh kreditor yang membebaskan debitor dari kewajibannya untuk memenuhi prestasinya. Pembebasan sesuatu utang tidak dipersangkakan, tetapi harus dibuktikan sebagaimana diatur dalam Pasal 1438 BW. Sehubungan dengan pembuktian maka pada Pasal 1439 BW menyatakan "Pengembalian sepucuk tanda piutang asli secara sukarela oleh kreditor kepada debitor merupakan suatu bukti tentang pembebasan utangnya, bahwa terhadap kawan debitor yang turut berutang secara tanggung menanggung”.

Berdasarkan pasal tersebut maka dengan kembalinya bukti asli surat piutang (yang seharusnya ada pada kreditor) yang menunjukkan kewajiban untuk memenuhi pembayaran 
suatu utang tertentu oleh debitor kepada kreditor, pada debitor, demi hukum menghapuskan utang atau kewajiban debitor untuk memenuhi pembayaran sejumlah utang yang disebutkan dalam surat piutang tersebut. ${ }^{13}$

\section{Kesimpulan}

Dalam menangani risiko hukum pembiayaan, bank syariah melakukan upaya yang didasarkan pada dua strategi, yaitu melakukan restrukturisasi pembiayaan atau menyelesaikan pembiayaan. Strategi yang dipergunakan oleh bank syariah dalam penanganan risiko hukum pada pembiayaan tersebut dibedakan menjadi 2 (dua), yaitu didasarkan pada nasabah beritikad baik dan nasabah yang beritikad buruk. Hal ini akan mempengaruhi upaya yang dilakukan oleh bank syariah dalam menanganinya.

Pada nasabah yang sejak awal beritikad baik maka bank syariah melakukan upaya restrukturisasi didasarkan pada akad pembiayaan, dan apabila upaya restrukturisasi tidak membawa hasil maka bank syariah dapat melakukan upaya eksekusi jaminan apabila ada, akan tetapi apabila tidak ada jaminan maka diselesaikan sengketa tersebut lewat Basyaranas atau litigasi, atau dapat dilakukan upaya dengan sukarela nasabah menyerahkan agunan dikenal dengan istilah AYDA. Sedangkan untuk nasabah yang sejak awal tidak beritikad buruk maka bank syariah dapat melakukan upaya eksekusi jaminan bila ada, akan tetapi apabila tidak ada jaminan yang mengcover maka sengketa tersebut diselesaikan lewat Basyarnas atau litigasi sesuai dengan kesepakatan para pihak yang dituangkan dalam akad. Upaya hapus buku dan hapus tagih hanya dapat dilakukan setelah bank syariah apabila telah melakukan berbagai upaya untuk memperoleh kembali Aktiva Produktif yang diberikan.

\section{Daftar Bacaan}

\section{Buku}

Al Quran Disertai Terjemahan dan Transliterasi, Mizan Pustaka, 2010.

Dewi, et.al.., Hukum Perikatan Islam di Indonesia, Jakarta: Kencana, 2005.

Wijaya dan Mulyadi, Hapusnya Perikatan, Jakarta: Raja Grafindo, 2003.

Usanti, Prinsip Kehati-hatian Pada Transaksi Perbankan Syariah, Surabaya: Airlangga University Press, 2013.

\section{Peraturan Perundang-Undangan}

Undang-Undang Republik Indonesia Nomor 7 Tahun 1992 Tentang Perbankan Lembaran Negara Republik Indonesia Tahun 1992 Nomor 31, Lembaran Negara Tahun 1992 Nomor 31. Tambahan Lembaran Negara Nomor 3472

Undang-Undang Republik Indonesia Nomor 10 Tahun 1998 Tentang Perubahan UndangUndang Nomor 7 Tahun 1992 Tentang Perbankan, Lembaran Negara Republik Indonesia Tahun 1998 Nomor 182. Tambahan Lembaran Negara Nomor 3790

13 Gunawan Wijaya dan Kartini Mulyadi, Hapusnya Perikatan, RajaGrafindo, 2003 h. 173. 
Undang-Undang Republik Indonesia Nomor 3 Tahun 2006 Tentang Perubahan Atas UdangUndang Nomor 7 Tahun 1989 Tentang Peradilan Agama. Lembaran Negara Republik Indonesia Tahun 2006 Nomor 22

Undang-Undang Republik Indonesia Nomor 21 Tahun 2008 Tentang Perbankan Syariah, Lembaran Negara Republik Indonesia Tahun 2008 Nomor 94

Kompilasi Hukum Ekonomi Syariah, Peraturan Mahkamah Agung Nomor 2 Tahun 2008.

Peraturan Bank Indonesia Nomor 8/21/PBI/2006 tentang Penilaian Kualitas Aktiva Bank Umum Yang Melaksanakan Kegiatan Usaha Berdasarkan Prinsip Syariah sebagaimana telah diubah dengan Peraturan Bank Indonesia Nomor 9/9/PBI/2007

Peraturan Bank Indonesia Nomor 10/PBI/2008 Tentang Restrukturisasi Pembiayaan Bagi Bank Syariah dan Unit Usaha Syariah

Peraturan Bank Indonesia Nomor 13/23/PBI/2011 tentang Penerapan Manajemen Risiko Bagi Bank Umum Syariah dan Unit Usaha Syariah

Peraturan Bank Indonesia Nomor 13/2/PBI/2011 tentang Pelaksaan Fungsi Kepatuhan Bank Umum

SEBI No.13/18/DPbS tanggal 30 Mei 2011 Tentang Perubahan atas SEBI Nomor 10/34/ DPbS tanggal 22 Oktober 2008 Tentang Restrukturisasi Pembiayaan Bagi Bank Syariah dan Unit Usaha Syariah

Peraturan Bank Indonesia Nomor 13/9/PBI/2011 tentang Penilaian Kualitas Aktiva Bank Umum Yang Melaksanakan Kegiatan Berdasarkan Prinsip Syariah

Peraturan Bank Indonesia Nomor 14/15/PBI/2012 tentang Penilaian Aset Bank Umum

Fatwa Dewan Syariah Nasional Nomor.7/DSN-MUI/IV/2000 tentang pembiayaan mudharabah

Fatwa Dewan Syariah Nasional Nomor 8/DSN-Mui/IV/2000 tentang pembiayaan musyarakah.

Fatwa Dewan Syariah Nasional Nomor 19/DSN-MUI/IV/2001 tentang Al-Qardh.

Fatwa Dewan Syariah Nasional Nomor 27/DSN-MUI/III/2002 tentang Al Ijarah Muntahiyah Bit Tamlik

Fatwa Dewan Syariah Nasional Nomor 46/DSN-MUI/II/2005 tentang Potongan Tagihan Murabahah (Khashm Fi Al-Murabahah)

Fatwa Dewan Syariah Nasional Nomor 49/DSN-MUI/II/2005 tentang Konversi Akad Murabahah

Fatwa Dewan Syariah Nasional Nomor 54/DSN-MUI/X/2006 tentang Syariah Card 
Yuridika: Volume 29 No 1, Januari - April 2014

Fatwa Dewan Syariah Nasional Nomor 73/DSN-MUI/XI/2008 Tentang Musyarakah Mutanaqisah

Putusan Mahkamah Konstitusi Nomor Nomor 93/PUU-X/2012 pada tanggal 29 Agustus 2013 